\title{
The Twin Bambili Maars (Bamenda Mountains, Cameroon Volcanic Line): Simulative Model of Formation
}

\author{
Wotchoko Pierre1*, Takojio Nguemo Rose Eugenie ${ }^{2}$, Kouankap Nono Gus Djibril1, \\ Guedjeo Christian Suh ${ }^{1,3}$, Nkouathio David Guimollaire ${ }^{3}$, Bobga Stanley Babila1,3, \\ Chenyi Marie-Louise Vohnyuii,3, Tchokona Seuwi dieudonne ${ }^{4}$, Suh Emmanuel Cheo ${ }^{5}$ \\ ${ }^{1}$ Department of Geology, Higher Teacher Training College, University of Bamenda, Bambili, Cameroon \\ ${ }^{2}$ Institut de Recherche Géologique et Minière, Laboratoire de Traitement des Minerais, Yaoundé, Cameroon. \\ ${ }^{3}$ Department of Earth Sciences, Faculty of Sciences, University of Dschang, Dschang, Cameroon \\ ${ }^{4}$ Department of Earth Sciences, Faculty of Sciences, University of Yaoundé 1, Yaoundé, Cameroon \\ ${ }^{5}$ Economic Geology Unit, Department of Geology and Environmental Science, University of Buea, Buea, Cameroon \\ Email: *pierrewotchoko@yahoo.fr, rose_nguemo@yahoo.fr, kouankap@yahoo.fr, guedjeochristian@yahoo.fr, \\ nkouathio@yahoo.fr, stanley.bobga@yahoo.com, tchokonaseuwui@yahoo.fr, lbeyeh@yahoo.com
}

How to cite this paper: Pierre, W., Eugenie, T.N.R., Djibril, K.N.G., Suh, G.C., Guimollaire, N.D., Babila, B.S., Vohnyui, C.M.-L., dieudonne, T.S. and Cheo, S.E. (2017) The Twin Bambili Maars (Bamenda Mountains, Cameroon Volcanic Line): Simulative Model of Formation. Open Journal of Geology, 7, 443-456.

https://doi.org/10.4236/ojg.2017.74030

Received: November 25, 2016

Accepted: April 11, 2017

Published: April 14, 2017

Copyright ( 92017 by authors and Scientific Research Publishing Inc. This work is licensed under the Creative Commons Attribution International License (CC BY 4.0).

http://creativecommons.org/licenses/by/4.0/ (c) (i) Open Access

\begin{abstract}
The Bambili maars are twin contemporaneous maars embedded in trachytic rocks. The two maars are separated by a low lying inter-Maar dome whose inner walls dip towards the Southern Maar. The Bambili Northern Maar (BNM) contains water and its floor is found at an altitude lower than the Bambili Southern Maar (BSM) (50 m) which is swampy and drains into the BNM. Both maars have very steep vertical walls. Three different units are identified in the area. Unit 1 is $1 \mathrm{~m}$ thick sequence, characterize by the presence of matrix supported fine-grained fallouts (ash and lapilli size) with stratified diffused bedding planes. This unit is further subdivided into three different layers: L1, L2 and L3 from bottom to top with increasing sizes of particles respectively. This layer shows reverser grading and its grain sizes rarely exceed $2 \mathrm{~cm}$ and this unit shows no depositional structures. Unit 2 is an unstratified unit predominantly made up of tephra deposits. Within these deposits are found blocks of sizes ranging between 2 and $10 \mathrm{~cm}$ of different petrographic types. They include scoria, basalts, trachyte, and granite cognate. The last unit, Unit 3 is distinctly stratified characterized by well sorted, heterolithologic, graded bedding layers which are matrix supported. Base on the composition and grain sizes, this unit was subdivided into 7 horizons: h1 - h7. Within this unit, two sequences of deposits are distinguished: $\mathrm{U} 1$ and $\mathrm{U} 2$. Both sequences are characterized by alternation of lapilli and tuff beds. The clast comprises of juvenile materials, mudstone which are highly vesicular and altered rock
\end{abstract}


fragments. Other products identified within the area are ferolithic volcanic bombs $(5-20 \mathrm{~cm})$, xenocrystals $(2-4 \mathrm{~cm})$ within finer deposits. They are elongated and show visible twinned planes. Explosion breccias are equally identified occurring as bolders. Along the inner walls of the maars are also found large basaltic and trachytic blocks which are remnants of pre-maar unit within maar deposits. The model proposed indicates the maars were emplaced simultaneously from adjacent vents followed by a succession of lava flows and pyroclastic ejections.

\section{Keywords}

Maar, Bambili, Dynamisms, Model

\section{Introduction}

Maars are characterized by steep-sided walls which cut below the pre-eruptive surface. They are commonly filled with water and surrounded by low-lying outward-dipping ejecta layers whose thickness thins are away from the vent rim. A maar's physical attribute is closely related to its mode of formation. In cases where a substantial disruption takes place below the surface, the ejection of material opens temporalcavities that collapse to forma maar [1] [2]. Maars originate from a "wet" eruption (phreatomagmatic) when magmacomes in contact with external water source e.g. ground water [3] or a surficial body of water [4]. Two types of maars can be distinguished; hard-substrate and soft-substrate maars, displaying distinct surficial expressions [5] [6]. The former is produced when magma interacts with water in fractured or jointed aquifers, and the latter formed when magma interacts with wet unconsolidated sediment or pore aquifers with high permeability [5] [6]. The study of maars has been intensified worldwide, laying more emphasis on the eruption energy and hazards related to the history of their formation [2]. Also, researchers study maar volcanoes to acquire paleoclimatic data and underground mapping [7].

Volcanic activities in Cameroon are localized along the Cameroon Volcanic Line (CVL), which is a major lineament in Africa about $1700 \mathrm{~km}$ in length and 100 $\mathrm{km}$ wide trending NE-SW [8] [9]. The CVL is made up of an oceanic and a continental sector. The continental sector is dotted with at least 40 lakes [10] (Table 1), some of which are maars. Some studied maars along this line include: Nyos [11], Monoun [12], Barombi Koto [13], Barombi Mbo [14] and Debunscha [15]. The Mount Bamenda $(2621 \mathrm{~m})$ occupies a surface area of $600 \mathrm{~km}^{2}$ and it is couple with the Bambouto Mountains $(2740 \mathrm{~m})$ and the Oku Mountain $(3011 \mathrm{~m})$ (Figure $1(\mathrm{a})$ ). It lies between longitudes $10^{\circ} 00^{\prime} \mathrm{E}$ and $10^{\circ} 30^{\prime} \mathrm{E}$ and latitudes $05^{\circ} 45^{\prime} \mathrm{N}$ and $06^{\circ} 10^{\prime} \mathrm{N}$ (Figure $1(\mathrm{~b})$ ). It constitutes in volumetric importance the fourth largest volcano of the CVL after Mount Cameroon, Mount Manengouba and Mount Bambouto [16]. These mountains constitute the volcanic centers of the Western Cameroon Highlands (WCH) [17] and they are characterized by the predominance of felsic lavas over mafic ones [18] [19]. All rest on a Pan-African 
Table 1. Geographic and morphometric feature of Cameroon lakes: median crater rim height above the lake surface-rim; Maximum depth $Z_{\max }$; mean depth-Z; volume development-3 $Z / Z_{\max }$; relative depth- $Z_{\mathrm{r}}$.

\begin{tabular}{|c|c|c|c|c|c|c|c|c|}
\hline \multirow{2}{*}{ No } & \multirow{2}{*}{ Lake } & \multirow{2}{*}{ Elev (m asl) } & \multirow{2}{*}{ Area (ha) } & Rim & $\mathrm{Z}_{\text {max }}$ & $\mathrm{Z}$ & \multirow{2}{*}{$3 Z / Z_{\max }$} & \multirow{2}{*}{$\begin{array}{c}\mathrm{Z}_{\mathrm{r}} \\
(\%)\end{array}$} \\
\hline & & & & & (m) & & & \\
\hline 1 & Ossa & 1 & 1300 & 10 & - & - & - & - \\
\hline 2 & Debundsha & 54 & 6 & 40 & 13.5 & - & - & 4.88 \\
\hline 3 & S. Debundsha & 54 & 1 & 10 & - & - & - & - \\
\hline 4 & Mboandong & 143 & 20 & 5 & - & - & - & - \\
\hline 5 & B. Kotto & 106 & 140 & 30 & 5.5 & 4.5 & 2.45 & 0.34 \\
\hline 6 & BarombiMbo & 301 & 415 & 100 & 110 & 68.7 & 1.87 & 4.78 \\
\hline 7 & Disoni & 455 & 165 & 100 & 80 & 41.2 & 1.54 & 5.52 \\
\hline 8 & Manengouba-F & 1920 & 22 & 100 & 168 & 61.8 & 1.10 & 31.7 \\
\hline 9 & Manengouba-M & 1900 & 2 & 70 & 92 & 55 & 1.79 & 57.6 \\
\hline 10 & Beme & 500 & 60 & 60 & 14.5 & - & - & 1.66 \\
\hline 11 & Mfouet & 1120 & 7 & 70 & 14 & - & - & 4.69 \\
\hline 12 & Baleng & 1374 & 8 & 70 & 52 & - & - & 16.3 \\
\hline 13 & Mfou & 1350 & 8 & 200 & 58 & - & - & 18.2 \\
\hline 14 & Negopghang & 1120 & 8 & 70 & 23 & - & - & 7.21 \\
\hline 15 & Monoum & 1080 & 53 & 20 & 96 & 25.8 & 0.81 & 11.7 \\
\hline 16 & Banefo & 1100 & 6 & 20 & 64 & - & - & 23.2 \\
\hline 17 & L.Monoum & 1100 & 25 & 30 & 49 & - & - & 8.69 \\
\hline 18 & Petponoun & 1120 & 30 & 3 & 12 & - & - & 1.94 \\
\hline 19 & Nchout & 1140 & 13 & 40 & 16 & - & - & 3.93 \\
\hline 20 & Ejagham & 100 & 70 & 10 & 17 & 11.4 & 2.01 & 1.80 \\
\hline 21 & Bambuluwe & 2053 & 28 & 50 & 58 & 39.3 & 2.03 & 9.71 \\
\hline 22 & Bambili I & 2264 & 28 & 100 & 4 & - & - & 1.49 \\
\hline 23 & Oku & 2227 & 243 & 80 & 52 & 32 & 1.85 & 2.96 \\
\hline 24 & Enep & 697 & 50 & 200 & 78 & - & - & 2.96 \\
\hline 25 & Elum & 960 & 50 & 120 & 35 & - & - & 9.78 \\
\hline 26 & Wum & 1177 & 45 & 20 & 124 & 48.4 & 1.17 & 4.39 \\
\hline 27 & Nyi & 1316 & 50 & 50 & 47 & - & - & 15.5 \\
\hline 28 & Nyos & 1091 & 158 & 70 & 208 & 111.7 & 1.61 & 14.7 \\
\hline 29 & Njupi & 1020 & 30 & 10 & - & - & - & - \\
\hline 30 & Gegouba & 1180 & 30 & 30 & 104 & - & - & 20.6 \\
\hline 31 & Ngaoundaba & 1160 & 10 & 30 & 62 & - & - & 17.4 \\
\hline 32 & Baledjam & 1249 & 25 & 15 & 13 & - & - & 2.3 \\
\hline 33 & Tizong & 1160 & 8 & 70 & 48 & 26.2 & 1.64 & 15 \\
\hline 34 & Massot & 1054 & 5 & 5 & - & - & - & - \\
\hline 35 & Mbalang & 1130 & 50 & 40 & 52 & 30 & 1.73 & 6.52 \\
\hline 36 & Dang & 1079 & 80 & 5 & - & - & - & - \\
\hline 37 & Bini & 1079 & 20 & 5 & - & - & - & - \\
\hline 38 & Benakuma & 576 & 154 & 200 & 138 & - & - & 9.86 \\
\hline 39 & Edib & 1280 & 2 & 60 & 12.5 & - & - & 7.83 \\
\hline$* 40$ & Bambili II & 2621 & 31 & - & - & - & - & - \\
\hline
\end{tabular}

Source: $[23]\left({ }^{*}\right)$ this paper. 

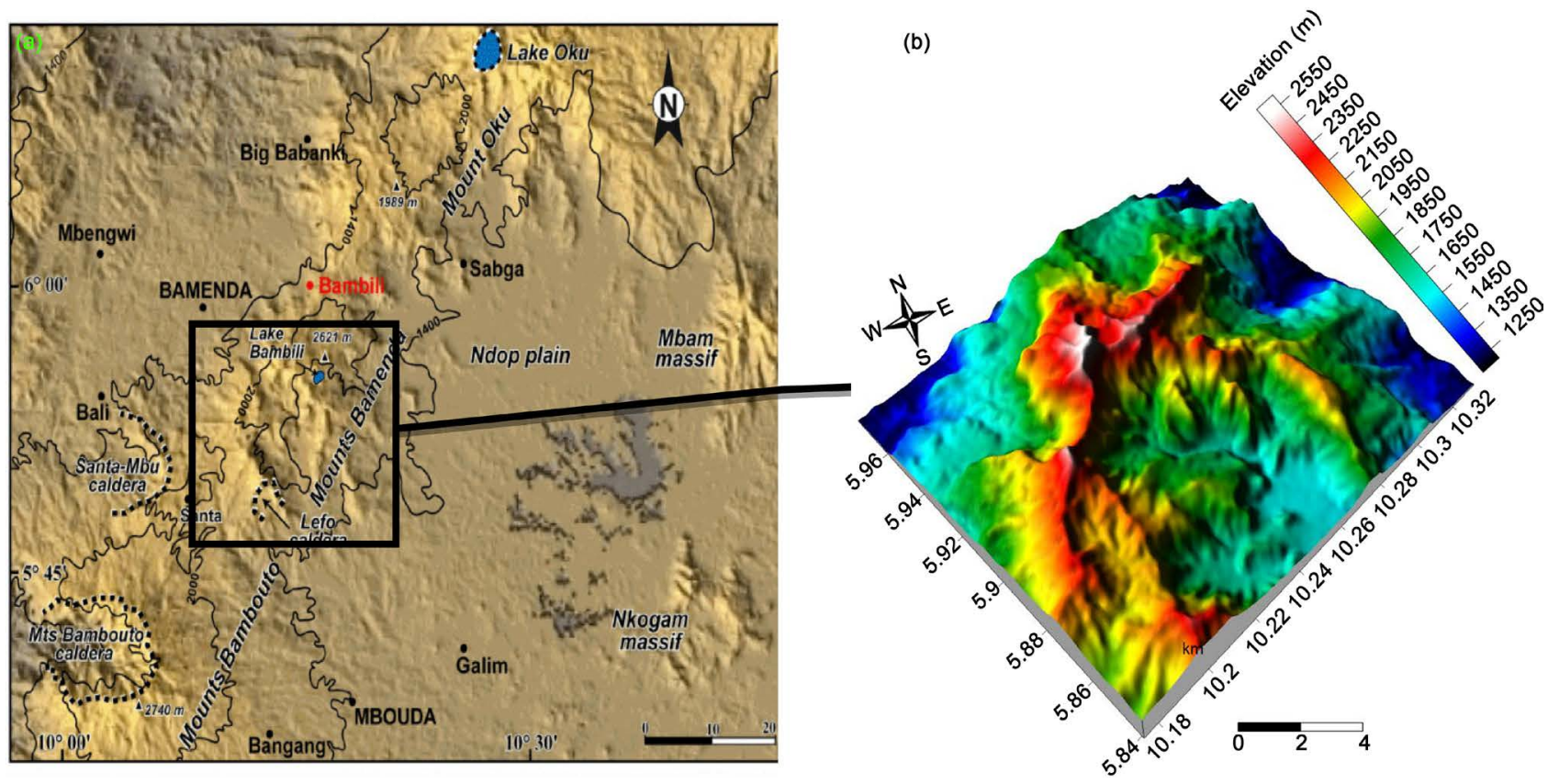

Figure 1. Map of study area. (a) Digital Elevation Model (DEM) of Mount Bamenda and surroundings (Bamenda mountain shown by Black square); Modified from [17]. (b) 3D view of Bamenda Mountain showing the Bambili maar (BM) at its summit (Black Square).

basement made up of granite and gneiss [20] [21] [22].

\section{Methodology}

This paper presents the physical volcanic history of the Bambili twin maarson the $\mathrm{WCH}$ and focuses on its mode of emplacement. Field investigations were made on different deposits in and around the maars in order to identify and classify the different pyroclastic materials ejected. From field photographs and field observations the relationships between the maars were described especially morphological parameters like size and height. The layers of the different pyroclastic units were differentiated and described taking into consideration their contrasting internal features such as grain size distribution, thickness, relative sorting, structures and components (juvenile and non-juvenile). Clasts size determination, shapes and types were limited to qualitative appreciations and a pre-hypothesis for the mechanism of emplacement conceived. The findings in this paper will greatly enhance the understanding of volcanic history of maars in the region and along the CVL.

\section{Results}

\subsection{Geomorphic Features of the Bambili Maars (BM)}

The BM is a bowl-shaped depression with steep-sided walls that cut through trachytic rocks and surrounded by a rim which decreases in radius away from the vent. The Bambili northern maar (BNM) is situated $50 \mathrm{~m}$ below the Bambili southern maar (BSM) (Figure 2) and both are linked by a stream [24]. Field observation and data treatment of (DEM) clearly reveal that the BSM has a larger 


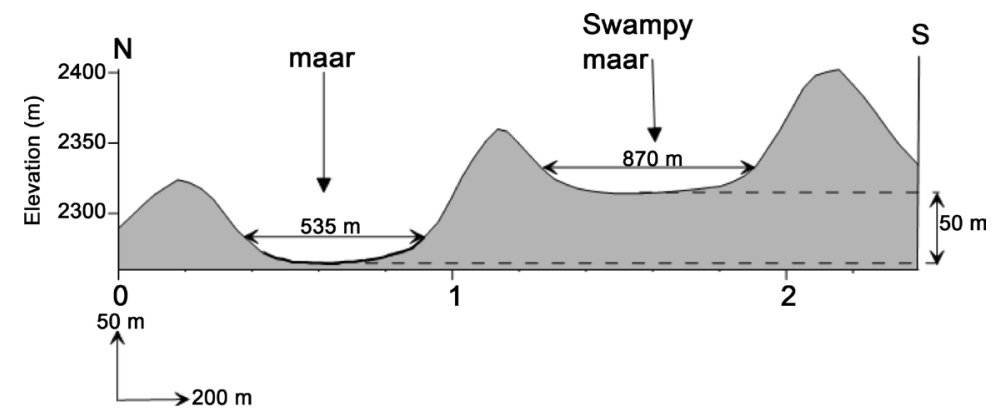

Figure 2. Cross of the Bambili maars.

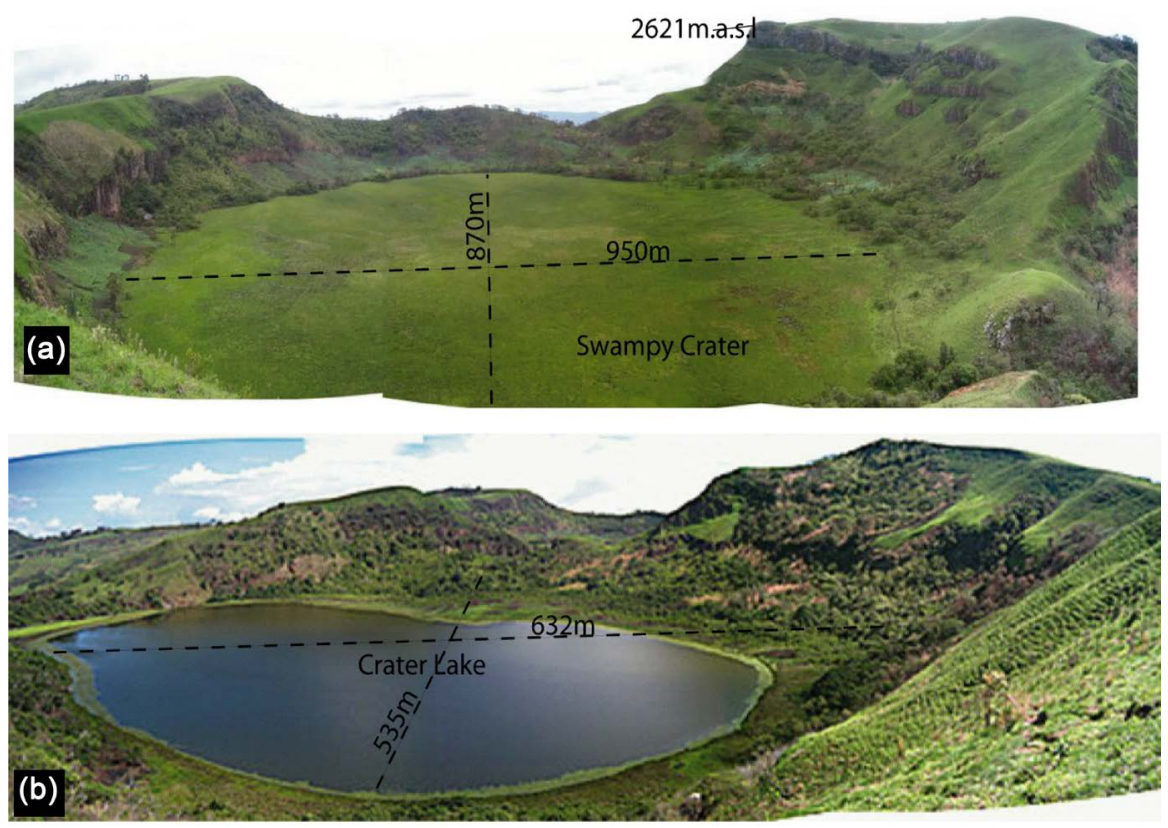

Figure 3. Photographs of Bambili maars; (a) Field image of BSM; (b) Field image of BNM.

size than the BNM (Figure 3). The BNM has an outlet in the northeast direction towards the Bambili village. The BSM has a diameter of 31 ha and its floor is found at an altitude of $2313 \mathrm{~m}$. The peak of the Bamenda Mountain is found at the border of BSM which measures $2621 \mathrm{~m}$. The western wall of the BSM is made up of a series of steps (Figure 3(a)) forming an escarpment with gradient ranging between $60^{\circ}$ to $65^{\circ}$. The eastern walls of both BNM and BSM are straight with no steps and make an almost $90^{\circ}$ with the floors of the Maars.

\subsection{Field Description of Inner Wall Deposits of the Bambili Maars}

The inner deposits considered here are those found within the maars. Different types of deposits were identified within the inner walls.

- Xenoliths; these are large boulders of trachytic rocks (Figure 4(a)) observed which occasionally reach $3 \mathrm{~m}$ in length and contain large feldspar crystals at the foot of the escarpment within the BM. Feldspar crystals are elongated and randomly orientated within finer materials (Figure $4(\mathrm{~b})$ ). The sizes of these xenocryst range from $4 \mathrm{~cm}$ to few $\mathrm{mm}$. 


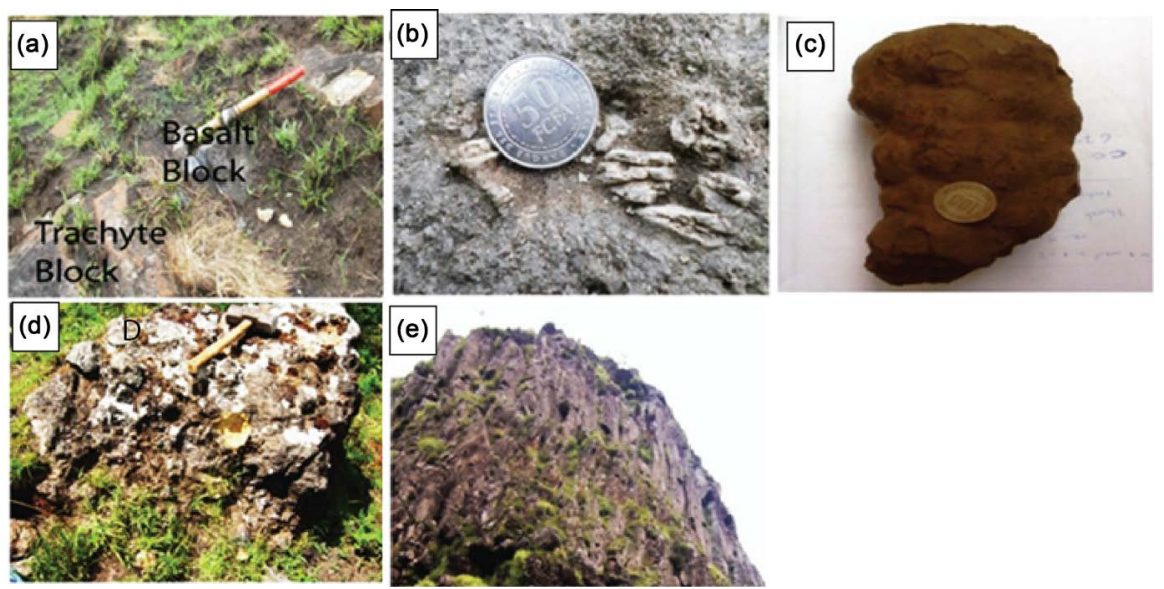

Figure 4. Photographs of marginal products in BM; (a) Trachyte and basalt blocks in tephra material; (b) Large feldspars crystals in trachyte found and the base of column; (c) Fusiform volcanic bomb; (d) Explosion breccias; (e) Trachytic columns bordering swampy maar (peak of Mount Bamenda).

- Explosion breccia; these deposits were observed around the outlet of the BNM and at the foot of the escarpment within the BSM. The explosion breccia is coarse grained, chaotic pyroclastic deposit consisting of coarse angular trachytic fragments, $2 \mathrm{~cm}$ to $15 \mathrm{~cm}$ in diameter (Figure 4(c)), within ash and lapilli matrix with average clasts size of less than $10 \mathrm{~cm}$ (Figure 4(d)).

- Bombs and blocks; the volcanic bombs are spiral (fusiform) while others are sub-rounded, having a reddish-brown color and occur within tephra deposit on the inner wall of the Maar. Some of the bombs have nodules on their surfaces (Figure 4(c)). The bomb sizes range between $2-20 \mathrm{~cm}$ and the nodules on their surfaces display exfoliation. Along the inner walls of the BM around the top of the rims, large isolated blocks of basalt and trachyte are observed within tephra fall outs (Figure 4(a)), and their sizes occasionally reach $1 \mathrm{~m}$ in diameter.

- Polygonal columns; the Bambili maars are emplaced within a trachytic rock whose upper portions are displayed in prisms (Figure 4(e)). These prisms are visible within the western inner walls of the BNM and have tetragonal to hexagonal faces. On the BSM, most of the prisms are covered by pyroclastic materials.

Generally, the two maars are separated by a trachytic intra maardome. The exposed part of the dome shows that the inner walls are dipping towards the BSM (Figure 5(a)). This phenomenon is also noted on the western inner walls of the BNM, (Figure 5(b)).

\section{Stratigraphic Units and Associated Pyroclastic Facies}

Three main stratigraphic sections were examined since the maar rims are completely covered by vegetation and the exposed columns at the borders of the maars are predominantly made up of pre-maar units. Two sections were examined on the western inner wall of the BNM and one section examined on the eastern inner wall of the BSM. 


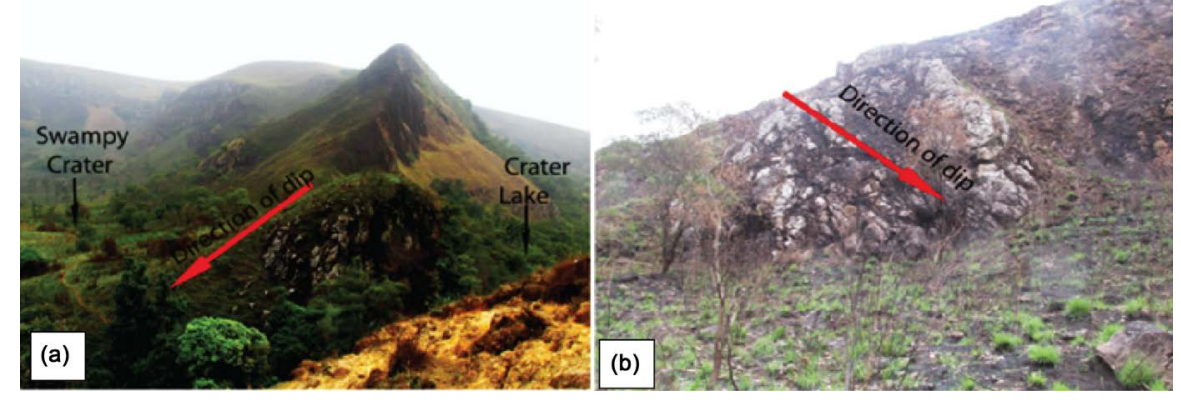

Figure 5. Photographs of tilted rocks (a) intra maardome dipping towards BSM (b) western inner wall of the BNM.
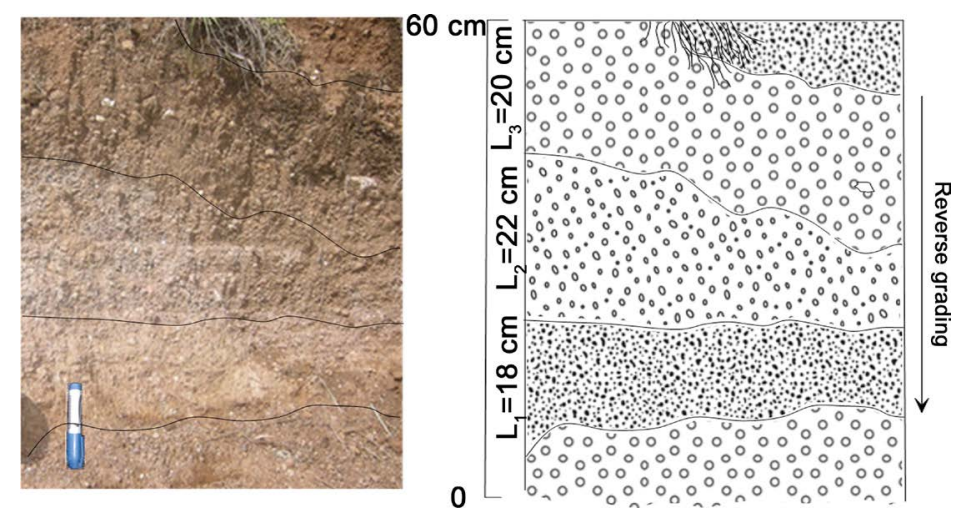

Figure 6. Stratigraphic column of unit 1.

\section{Unit 1: east of the BSM}

This unit has a thickness of $60 \mathrm{~cm}$ with its upper part marked by diffused stratified matrix supported by tephra. It is characterized by the presence of fine-grained fallouts (ash and lapilli size) with diffused bedding planes (Figure 6). The base of unit L1 $(18 \mathrm{~cm})$ is composed of consolidated ash. This layer has an orange-brown color with medium grain size rock fragments which rarely exceeds $3 \mathrm{~mm}$. It is overlain by an unsorted lapilli size layer L2 $(22 \mathrm{~cm})$. L2 has abundant larger clasts, orange grey in colour and angular to sub-angular whitish lithic fallouts. Above this bed lies a lithic rich mostly altered clasts L3 $(20 \mathrm{~cm})$. This layer is characterized by abundant and larger size accreational clasts which are mostly sub rounded in shape than the preceding L1 and L2 layers. It appears dark than the corresponding L1 and L2 layers and its clast sizes range between a few millimeters to centimeters. Clast size variation increases up-ward from L1 to L3.

\section{Unit 2: north of the BNM}

This unit is made up of non-stratified tephra deposits composed of coarse lapilli with variable fragment sizes of different petrographic types. The layer is brownish in colour containing juvenile (Volcanic bombs and scoria) and nonJuvenile (granitic) entrained fragments (Figure 7). Generally, clasts sizes within this unit vary from $2 \mathrm{~mm}$ to $10 \mathrm{~cm}$ (basalt bomb).

\section{Unit 3: between the BNM and BSM}

This unit is thicker around the BNM $(50 \mathrm{~m})$ and its thickness reduces towards 


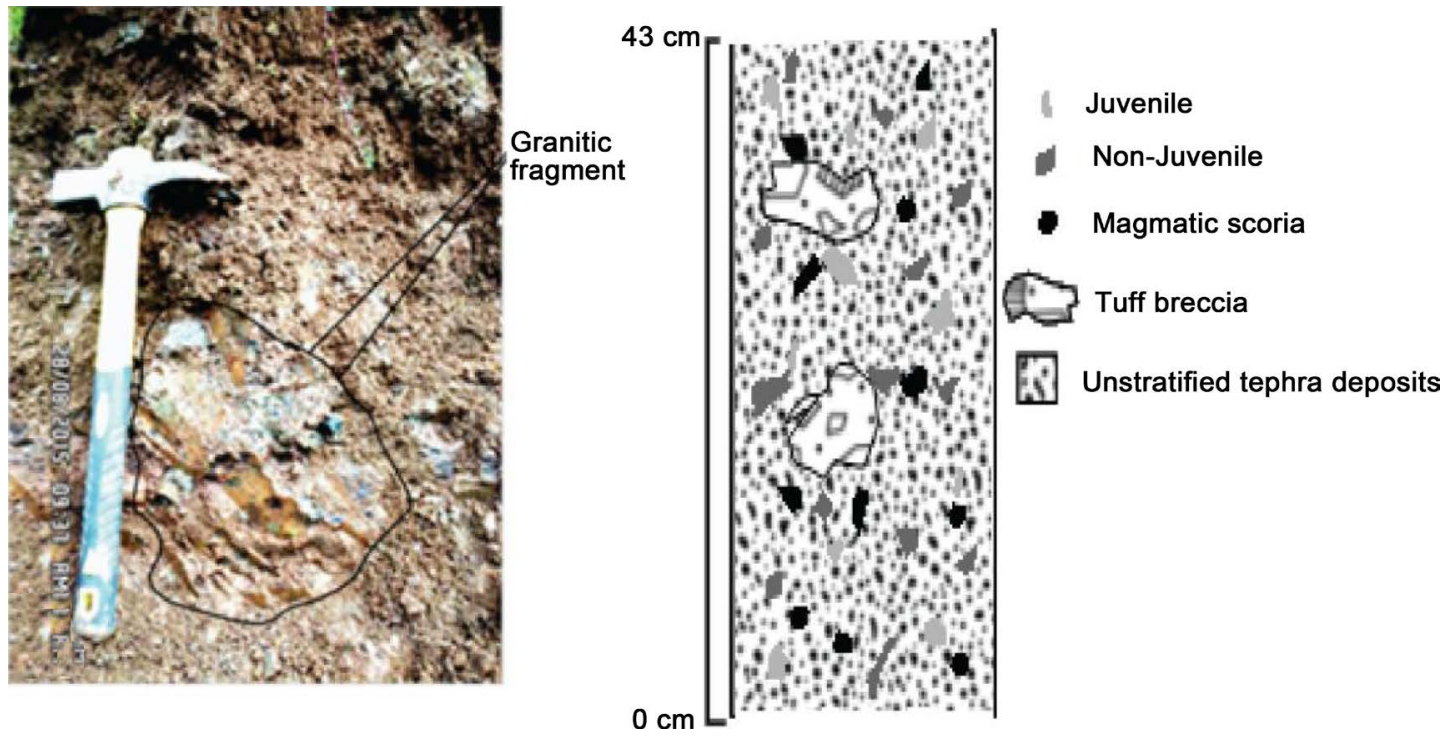

Figure 7. Stratigraphic column of Unit 2.

the BSM $(30 \mathrm{~m})$ disappearing towards the summit. This unit rest directly on trachytic rocks (pre-maar unit).It is marked by coarse grained lapilli interbedded with lapilli tuff and mudstone and abundant juvenile fragments. The unit is divided into two horizons; U1 and U2 (Figure 8). U1 is characterized by abundant lapilli, juvenile and non-juvenile fragments. It is sub-divided into h1 to h5 lacking lacks bomb sacs and accretionary lapilli, reverse grading and scarce trachytic blocks towards the top. U1 terminates with a layer of very coarse angular lapilli, altered blocks and scoria. U2 is well sorted and has larger clast sizes with the presence of mudstone. There is a strong variation in grain size ranging from fine-coarse lapilli with numerous interbedded blocks of trachyte and mudstone.

\subsection{Field Description of Outer Deposits}

The outer deposits of the maars are poorly represented and characterized mostly by scoria, ash and lava flow. Scoria deposits are found interbedded within the ash. The ash deposits lie at about $1 \mathrm{~km}$ away from the maar (Figure 9). The scoria has numerous vesicles of various sizes and shapes (Figure 9(a)).

\section{Discussions}

\subsection{Volcanic History of the Bambili Maars}

The study of volcanic products emitted from these maars reveals that three volcanic eruption styles (effusive, strombolian and phreatomagmatic) contributed to their formation. The effusive eruption here is represented by aa lava flows which outcrop as blocks and boulders with size ranging from $30 \mathrm{~cm}$ to $2 \mathrm{~m}$ in diameter. It has an estimated thickness of $10 \mathrm{~m}$. The flows outcrop about $1.5 \mathrm{~km}$ from the maars and also as blocks in tephra deposits of the BM. The strombolian eruption gives an origin of two tephra cones. These deposits consist of scoria bombs, lapilli and cinders with massive bedding. The tephra has abundant vesicles giving the lapilli and scoria a cindery appearance. They are asymmetrical 

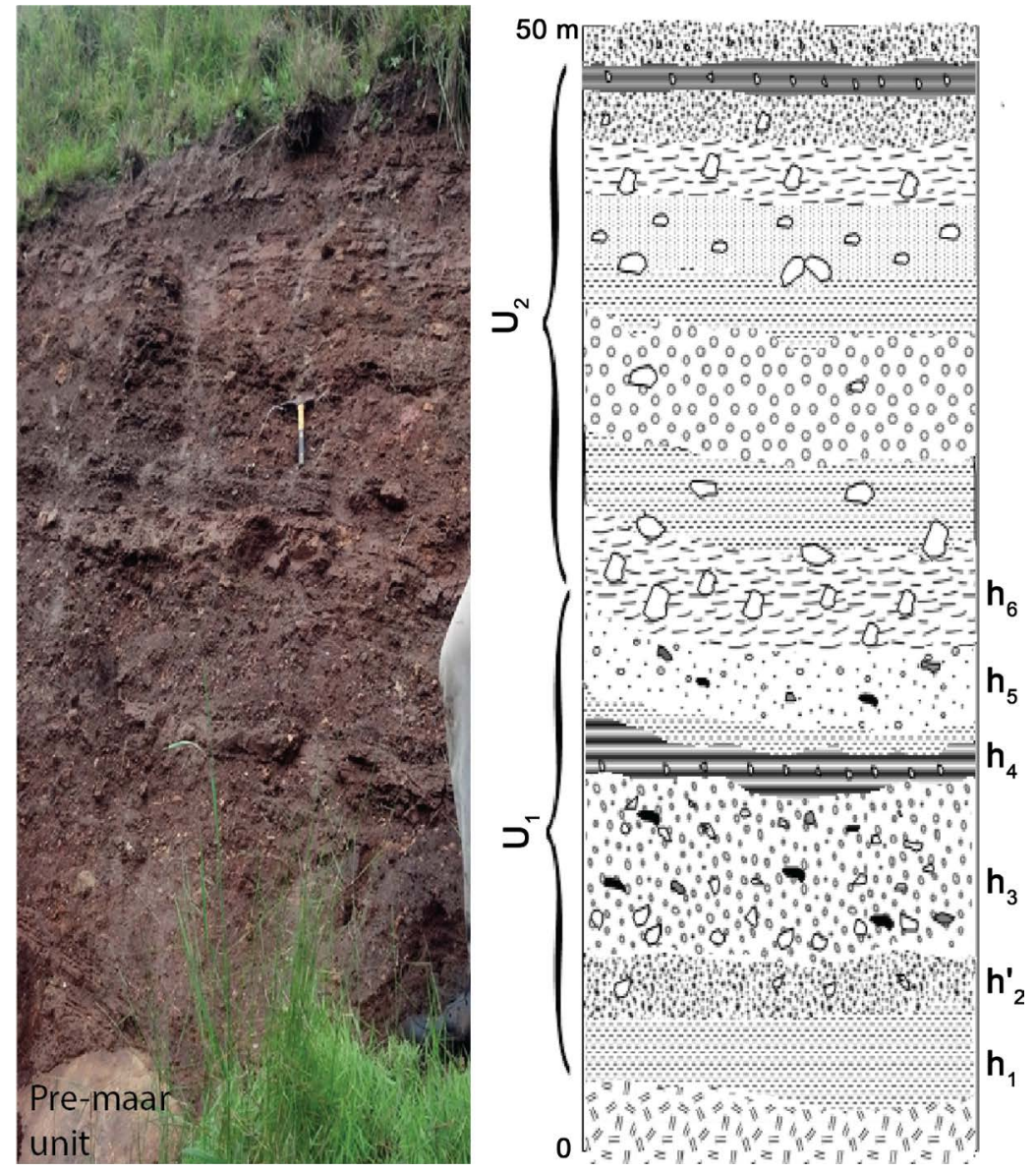

Figure 8. Stratigraphic column unit 3.

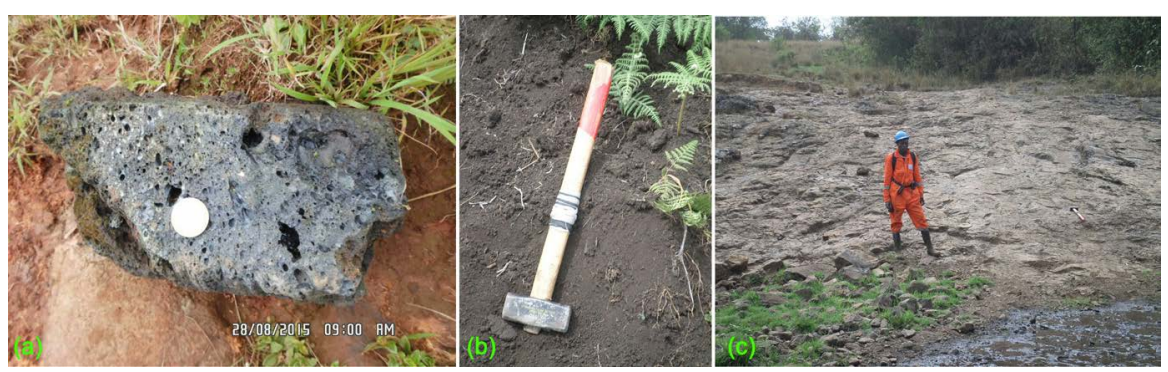

Figure 9. Erupted products; (a) highly vesicular scoria; (b) ash deposit further away from the vents; (c) a lava flows BSM.

having an average height of 140 meter with their slopes dipping at $11-15$ degree. During phreatomagmatic eruption, uprising magma comes in contact with water and generate enough pressure which triggered an explosion. Pre-existing lava fragments of about $3 \mathrm{~cm}$ were deposited closed to the BSM while finer cinder and ash fragments were deposited in the eastern direction to form unit 1 above. Air fall deposits on the west formed unit 3a graded-stratified phreatomagmatic deposit.

\subsection{Simulative Formation Model}

These maars were formed simultaneously from uprising magma which came in 
contact with ground water. This was followed by a series of lava flows which produced layers of lava and pyroclasts, then followed the collapse of the walls forming escarpments which surrounded the maars (Figure 10). The vents are slightly tilted towards the NW which is testified by the huge volume of tephra and lava deposits towards this direction.

The BNM contains a lake which suggests that the eruption cut through the water table represented today by the level of the water it contain, while the BSM is swampy and its water drains into the BNM. The differences in the altitude of the maar floor of both BNM and BSM clearly explain why water drains from the BSM into BNM. The inner walls of both maars are surrounded by step escarpments.
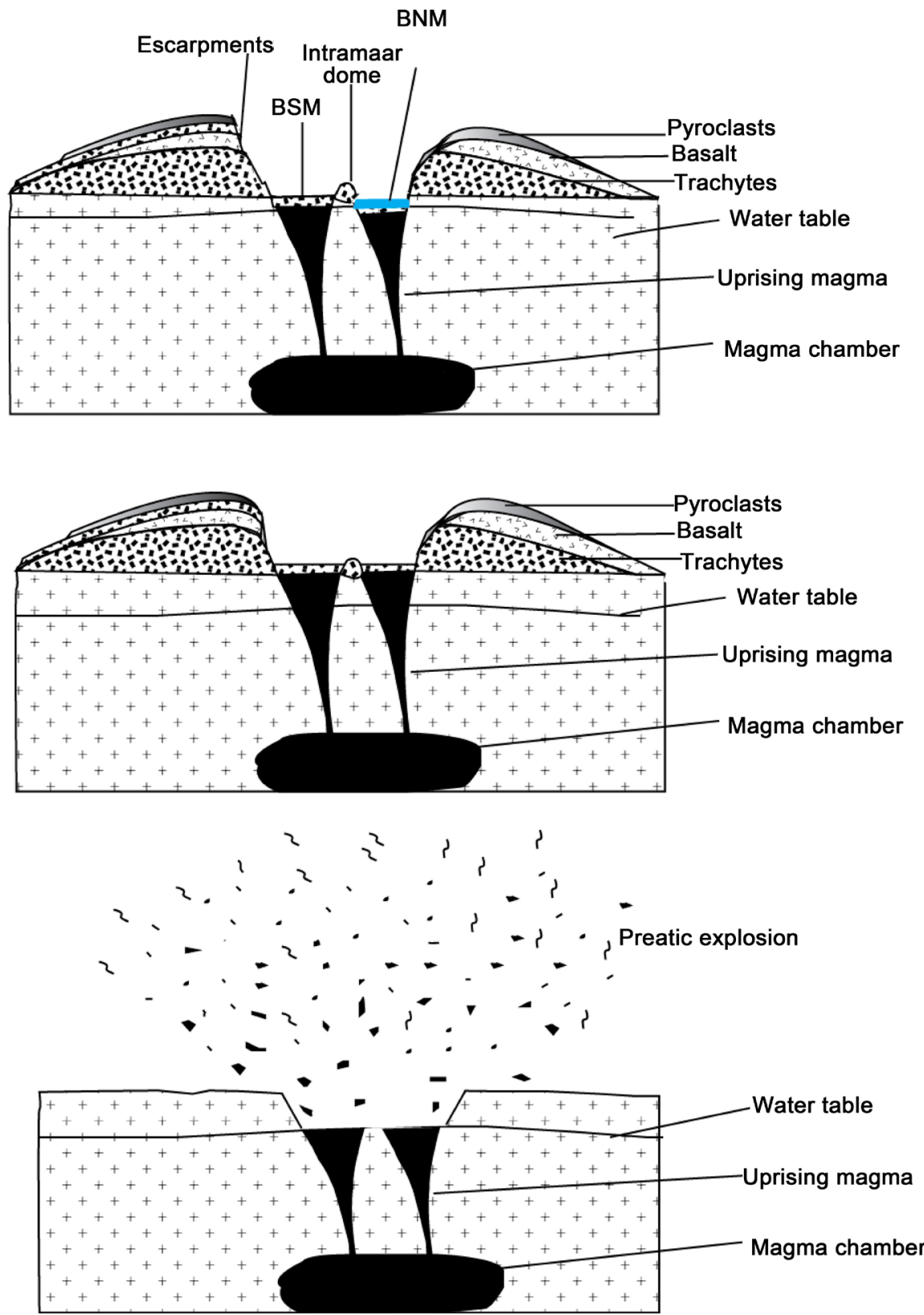

Figure 10. Formation of the Bambili maars. 
The heterolithologic nature of this rock found in both BSM and BNM cannot be attributed to transport-related sorting mechanisms, but to possible sub-surface processes, like: a higher degree of fragmentation, or a more prolonged phase of post-fragmentation transport and abrasion of the already formed basalts and trachyte in the volcanic conduit, or a higher degree of fracturation of country rocks [25]. The intra-maar dome and inner wall, which are tilted towards the swampy maar suggests a violent activity during its emplacement such that they were affected. Basalt and trachyte blocks are abundant in an approximate ratio of 3:1 respectively in BNM and BSM. This indicates that the fragmentation in the two conduits took place at different depths. Though it is suggested that the two eruptions took place at different levels, another possibility is that the cinder on the maar floor of the BSM might have been significant enough to fill this depression and then drop its water level. The pumicious fallouts around the dome shows that the last phase of the eruption was purely strombolian. The fusiform bomb will have resulted from a very hot fluid magma that chilled sufficiently enough during flight to retain the spindle shape and deposit by fall out. Basaltic bombs from unit 3 in BNM show low vesicularity, indicating that a greater amount of energy came from conversion of external water to steam; furthermore, the violent release of magmatic volatiles would have played a minor rule the eruption style [26] [27].

The chilled lava layer existing within the maar products (unit 3), suggests that a significant temperature difference existed between melt and the country rock at the initial contact [25] and equally the addition of water into the system. The abundance of accidental clasts in this unit indicates hydroclastic mechanisms that are characteristic for shallow phreatomagmatic eruptions. This unit is equally characterized by poor sorting and lacks fabric structures. This is usually attributed to high particle concentration rather than turbulence [28]. Sagging in unit 3 by mud stone fragments is an indication of abundant moisture and wetness of the environment [29] [30] [31] [32]. The mudstone lumps are intact, but slightly deformed and marginally altered within this deposit. This may provide further evidence for laminar flow conditions in the body of the pyroclastic flow. The elongated and angular crystals here considered as non-juvenile crystals may have been derived from the fragmentation of accessory or accidental lithics [28], and so, during the formation of the maar, the already formed crystals were destabilized and crushed while others remained large and the material then became consolidated after to form the whole mass. According to [33] such larger elongated crystal sizes may result from higher cooling rates at higher ejection velocities which blocks are seen at the surface.

The columnar jointed trachyte in the Bambili areas are similar to that described in Cancarixphrea to magmatic volcano in Spain [34], in which the columnar jointed rock formed the highest point on the volcano. Aspects of the BM are similar to some geological features along the CVL. Similar subvertical prismatic trachyte exists at the borders of the Lefo and Bambouto caldera [35]. 


\section{Conclusion}

The Bambili maars are emplaced within trachytic rocks. The swampy BSM situated at a higher altitude than the lake (BNM). The main eruptive styles are effusive, strombolian and phreatomagmatic which formed deposits such as xenoliths, explosion breccias, bombs and blocks, polygonal columns and lava flows. The studied maars deposits revealed three stratigraphic units. Unit 1 was characterized by the presence of fine-grained fallouts (ash and lapilli size) with diffused bedding planes. Unit 2 was made up of non-stratified tephra deposits composed of coarse lapilli with variable fragment sizes of different petrographic types and Unit 3 was marked by coarse grained lapilli interbedded with lapilli tuff and mudstone with abundant juvenile fragments. The proposed model for the emplacement revealed that the maars were emplaced simultaneously from two adjacent vents. This was followed by a succession of lava flow and pyroclastic ejections. The finding of this work shall give a perspective for geochemical and geochronological analysis to be performed on these formation to expound on the sequences of events.

\section{References}

[1] Lorenz, V. (1986) On the Growth of Maars and Diatremes and Its Relevance to the Formation of Tuff Rings. Bulletin of Volcanology, 48, 265-274. https://doi.org/10.1007/BF01081755

[2] Lorenz, V. and Kurszlaukis, S. (2007) Root Zone Processes in the Phreatomagmatic Pipe Emplacement Model and Consequences for the Evolution of Maar-Diatreme Volcanoes. Journal of Volcanology and Geothermal Research, 159, 4-32.

[3] Cashman, K., Thornber, C. and Kauahikaua, J. (1999) Cooling and Crystallization of Lava in Open Channels, and the Transition of Pāhoehoe Lava to "A"ā. Bulletin of Volcanology, 61, 306-323. https://doi.org/10.1007/s004450050299

[4] Sheridan, M.F. and Wohletz, K.H. (1983) Hydrovolcanism: Basic Considerations and Review. Journal of Volcanology and Geothermal Research, 17, 1-29.

[5] Lorenz, V., Suhr, P. and Goth, K. (2003) Maar-Diatrem-Vulkanismus-Ursachen und Folgen. Die Guttauer Vulkangruppe in Ostsachsenals Beispiel für die komplexen Zusammenhänge. Zeitschrift für Geologische Wissenschaften, 31, 267-312.

[6] Auer, A., Martin, U. and Nemeth, K. (2007) The Fekete-Hegy (Balaton Highland Hungary) "Soft-Substrate" and "Hard-Substrate" Maar Volcanoes in an Aligned Volcanic Complex-Implications for Vent Geometry, Subsurface Stratigraphy and the Palaeoenvironmental Setting. Journal of Volcanology and Geothermal Research, $150,225-245$

[7] Martín-Serrano, A., Vegas, J., Garcia-Cortes, A., Galan, L., Gallardo-Millan, J.L., Martin-Alfageme, S., Rubio, F.M., Ibarra, P.I., Granda, A. and Perez-Gonzalez, A.J.L. (2009) Morphotectonic Setting of Maar Lakes in the Campo de Calatrava Volcanic Field (Central Spain, SW Europe). Sedimentary Geology, 222, 52-63.

[8] Déruelle, B., Ngounouno, I. and Demaiffe, D. (2007) The "Cameroon Hot Line" (CHL): A Unique Example of Active Alkaline Intraplate Structure in Both Oceanic and Continental Lithospheres. Comptes Rendus Geoscience, 339, 589-600.

[9] Njome, M.S. and de Wit, M.J. (2014) The Cameroon Line: Analysis of an Intraplate Magmatic Province Transecting Both Oceanic and Continental Lithospheres: Constraints, Controversies and Models. Earth-Science Reviews, 139, 168-194. 
[10] Kling, G.W., Clark, M., Compton, H.R., Devine, J.D., Evans, W.C., Humphrey, A.M., Lockwood, J.P. and Tuttle, M.L. (1987) The 1986 Lake Nyos Gas Disaster, Cameroon, West Africa. Science, 236, 169-175. https://doi.org/10.1126/science.236.4798.169

[11] Aka, F.T., Yokoyama, T., Kusakabe, M., Nakamura, E., Tanyileke, G., Ateba, B., Ngako, V., Nnange, J. and Hell, J. (2008) U-Series Dating of Lake Nyos Maar Basalts, Cameroon (West Africa): Implications for Potential Hazards on the Lake Nyos Dam. Journal of Volcanology and Geothermal Research, 176, 212-224.

[12] Sigurdsson, H., Devine, J.D., Tchoua, F.M., Pressor, T.S., Pringle, M.K.W. and Evans, W.C. (1987) Origin of the Lethal Gas Burst from Lake Monoun, Cameroun. Journal of Volcanology and Geothermal Research 31, 1-16.

[13] Tamen, J., Nkoumbou, C., Mouafo, L., Reusser, E. and Tchoua, F.M. (2007) Petrology and Geochemistry of Monogenetic Volcanoes of the Barombi Koto Field (Kumba Graben, Cameroon Volcanic Line): Implication for Mantle Source Characteristics. Geoscience, 339, 799-809.

[14] Maley, J., Livingstone, D.A., Giresse, P., Thouveny, N., Brenac, P., Kelts, K., Kling, G. Stager, C., Haag, M., Fournier, M., Bandet, Y., Williamson, D. and Zogning, A. (1990) Lithostratigraphy, Volcanism, Paleomagnetism and Palynology of Quaternary Lacustrine Deposits from Barombi Mbo (West Cameroon): Preliminary Results. Journal of Volcanology and Geothermal Research, 42, 319-335.

[15] Ngwa., C.N., Suh, C.E. and Devey, C.W. (2010) Phreatomagmatic Deposits and Stratigraphic Reconstruction at Debunscha Maar (Mt Cameroon Volcano). Journal of Volcanology and Geothermal Research, 192, 201-211.

[16] Kagou Dongmo, A., Nkouathio, D., Nono, A., Kwekam, M., Tematio, P., Wandji, P., Tchoua, F., Pouclet, A. and Bourdier, J.-L. (2006) Discovery of Strombolian Cone at Totap-Tapsetsa, North-East Slope of Mount Bambouto: Implications in the Petrogenesis and the Volcanic Activity of Bambouto Volcano (Cameroon Line).

[17] Gountié Dedzo, M., Kamgang, P., Njonfang, E., Zangmo Tefogoum, G., Nkouathio, D.G. and Kagou Dongmo, A. (2015)Remnants Blocks of Pyroclastic Surge Deposits in Bambili, Cameroon Volcanic Line: New Insights into the Lithostratigraphy of Mount Bamenda. British Journal of Applied Science \& Technology, 7, 585-596. https://doi.org/10.9734/BJAST/2015/15958

[18] Kamgang, P. (2003) Petrology and Geochemistry of a Key Sector along the Cameroon Line, Mount Bamenda: Implication on the Genesis and Evolution of Magma. PhD Thesis, Université de Yaounde I, Yaounde, 373 p.

[19] Kamgang, P., Njonfang, E., Chazot, G. and Tchoua, F. (2007) Geochemistry and Geochronology of Felsic Lavas from Mount Bamenda (Cameroon Volcanic Line). Geoscience, 339, 659-666.

[20] Toteu, S.F., Van Schmus, W.R., Penaye, J. and Michard, A. (2001) New U-Pb and Sm-Nd Data from North-Central Cameroon and Its Bearing on the Pre-Pan African History of Central Africa. Precambrian Research, 108, 45-73.

[21] Nzolang, C., Kagami, H., Nzenti, J.P. and Holtz, F. (2003) Geochemistry and Preliminary Data on the Neoproterozoic Granitoids from the Bantoun Area, West Cameroon: Evidence for a Derivation from a Paleoproterozoic to Archean Crust. Polar Geoscience, 16, 196-226.

[22] Kwékam, M. (2005) Genesis and Evolution of Calco-Alkaline Granitoids during the Panafrican Tectonism: The Case of the Syn to Post Tectonic Massif of West-Cameroon (Dschang and Kekem Regions). Doctorat Thesis, University of Yaounde I, Yaounde, $201 \mathrm{p}$.

[23] Kling, G.W. (1988) A Comparative Transparency, Depth of Mixing, and Stability of 
Stratification in Lakes of Cameroon, West Africa. Limnology and Oceanography, 33, 27-40.

[24] Assi-Kaudjhis, C., Lezine, A.-M. and Roche, E. (2008)Dynamism of Altitude Vegetation in Central Atlantic Africa Since 17,000 Years BP. Preliminary Analysis of the Bambili Carrots. (North-West Cameroon). Geo-Eco-Trop, 32, 131-143.

[25] Sottilia, G., Taddeuccib, J., Palladino, D.M., Gaeta, M., Scarlato, P. and Ventura, G. (2009) Sub-Surface Dynamics and Eruptive Styles of Maars in the Colli Albani Volcanic District, Central Italy. Journal of Volcanology and Geothermal Research, 180, 189-202.

[26] Schmincke, H.U. (1977) Phreatomagmatische phasen in quartären vulkanen der Osteifel. Geologisches Jahrbuch Reihe, A39, 3-45.

[27] Befus, K.S., Hanson, R.E., Lehman, T.M. and Griffin, W.R. (2008) Cretaceous Basaltic Phreatomagmatic Volcanism in West Texas: Maar Complex at Pena Mountain, Big Bend National Park. Journal of Volcanology and Geothermal Research, 173, 245-264.

[28] Cas, R.F. and Wright, J.V. (1988) Volcanic Successions Modern and Ancient. Unwin Hynman, London, $528 \mathrm{p}$.

[29] Crowe, B.M. and Fisher, R.U. (1973) Sedimentary Structures in Base Surge Deposit with Special Reference to Cross Bedding, Ubehebe Craters, Death Valley, California. Geological Society of America Bulletin, 84, 663-682. https://doi.org/10.1130/0016-7606(1973)84<663:SSIBDW>2.0.CO;2

[30] Lorenz, V. (1974) Vesiculated Tuffs and Associated Features. Sedimentology, 21, 273-291. https://doi.org/10.1111/j.1365-3091.1974.tb02059.x

Sigurdsson, H., Devine, F.M., Tchoua, T.S., Pringle, M.K.W. and Evans, W.C. (1987) Origin of the Lethal Gas Bust from Lake Monoun, Cameroon. Journal of Geothermal Research, 31, 1-16.

[31] Lorenz, V. (1985) Maars and Diatremes of Phreatomagmatic Origin: A Review. Transactions of the Geological Society of South Africa, 88, 459-470.

[32] Nemeth, K., Martin, U. and Harangi, S. (2001) Miocene Phreatomagmatic Volcanism at Tihany (Pannonian Basin, Hungary). Journal of Volcanology and Geothermal Research, 111, 111-135.

[33] Zimanowski, B., Büttner, R., Lorenz, V. and Häfele, D. (1997) Fragmentation of Basaltic Melt in the Course of Explosive Volcanism. Journal of Geophysical Research, 102, 803-814. https://doi.org/10.1029/96JB02935

[34] Seghedi, L., Szakacs, A., Hernandez, P.A. and Brandle Matesanz, J.L. (2007) Miocene Lamproite Volcanoes in South-Eastern Spain an Association of Phreatomagtic and Magmatic Products. Journal of Volcanology and Geothermal Research, 159, 210-224.

[35] Gountié Dedzo, M., Njonfang, E., Kamgang, P., Nono, A., Zangmo Tefogoum, G., Kagou Dongmo, A. and Nkouathio, D.G. (2012) Dynamic and Evolution of the Mounts Bambouto and Bamenda. Calderas by Study of Ignimbritic Deposits (West-Cameroon, Cameroon Line). Syllabus Review, 3, 11-23. 
Submit or recommend next manuscript to SCIRP and we will provide best service for you:

Accepting pre-submission inquiries through Email, Facebook, LinkedIn, Twitter, etc. A wide selection of journals (inclusive of 9 subjects, more than 200 journals)

Providing 24-hour high-quality service

User-friendly online submission system

Fair and swift peer-review system

Efficient typesetting and proofreading procedure

Display of the result of downloads and visits, as well as the number of cited articles Maximum dissemination of your research work

Submit your manuscript at: http://papersubmission.scirp.org/

Or contact ojg@scirp.org 